\title{
Promotive and preventive programs of heavy infection knowledge in Medan Barat district
}

\author{
Bastian Lubis ${ }^{1 *}$, Putri Amelia ${ }^{1}$, Muhammad Akil $^{1}$ \\ ${ }^{1}$ Faculty of Medicine, Universitas Sumatera Utara, Medan, Indonesia \\ *Email: bastian.lubis@usu.ac.id
}

\begin{abstract}
Sepsis is still an important health problem in the world today. The incidence of sepsis can reach 750,000 cases per year. When mothers have a vital role in family health, their lack of knowledge and concern about sepsis remains an obstacle. Therefore, we need a program to promote and prevent sepsis among mothers in West Medan District as an effort to reduce the number of sepsis in Indonesia. Coaching, training, and counseling are given to PKK mothers and Posyandu cadres regarding the prevention of severe infections that can cause sepsis. This activity began by collecting basic data using the Sepsis Knowledge Scale questionnaire and then provided counseling and training on sepsis. Then, the final results were assessed with a behavioral questionnaire and sepsis knowledge questionnaire. The activity was attended by 29 people, 20 women (72.4\%) and 9 men $(27.6 \%)$. No significant changes were found in the level of knowledge and behavior before and after the activity (Z-score: $0.001 ; \mathrm{p}=1,000)$.
\end{abstract}

Keyword: Severe infections, PKK, Posyandu, Sepsis

\begin{abstract}
Abstrak
Sepsis masih menjadi permasalahan kesehatan yang penting di dunia saat ini. Angka kejadian sepsis dapat mencapai 750.000 kasus per tahun. Ketika para ibu memiliki peran vital dalam kesehatan keluarga, kurangnya pengetahuan dan kepedulian mereka mengenai sepsis masih menjadi suatu hambatan. Oleh karena itu, diperlukan suatu program untuk promotif dan preventif sepsis pada kalangan ibu-ibu di Kecamatan Medan Barat sebagai upaya menurunkan angka sepsis di Indonesia. Pembinaan, pelatihan, dan penyuluhan diberikan kepada orang ibu-ibu PKK dan kader Posyandu mengenai pencegahan terjadinya infeksi berat yang dapat menyebabkan sepsis. Kegiatan ini dimulai dengan mengumpulkan data dasar menggunakan kuesioner Sepsis Knowledge Scale kemudian diberikan penyuluhan dan pelatihan mengenai sepsis. Kemudian, hasil akhir dinilai dengan kuesioner perilaku dan kuesioner pengetahuan sepsis. Kegiatan dihadiri oleh 29 orang, 20 perempuan (72,4\%) dan 9 lakilaki (27,6\%). Tidak ditemukan perubahan signifikan dari tingkat pengetahuan dan perilaku sebelum dan sesudah kegiatan (Z-score: 0,$001 ; p=1,000)$.
\end{abstract}

Kata Kunci: Infeksi Berat, PKK, Posyandu, Sepsis

\section{PENDAhuluan}

Sepsis masih menjadi problem didunia saat ini. Sepsis merupakan penyebab utama mortalitas. Angka kejadian sepsis dapat mencapai 750.000 kasus per tahun (Bone, et.al. 1992). Sepsis merupakan salah satu penyebab kematian terbesar sehingga penatalaksanaan yang baik dan sesuai dengan pedoman diperlukan untuk menurunkan angka morbiditas dan mortalitas (Patrick, J.N. 2006). Telah dilaporkan angka kejadian sepsis meningkat dari 82,7 menjadi 240,4 pasien per 100.000 populasi antara tahun 1979 - 2000 di Amerika Serikat. Penelitian retrospektif di Norwegia dari tahun 2011 dan 2012 dari 13582 dijumpai angka mortalitas sepsis sekitar 26.4\% (Knoop, et.al. 2017). Angka kematian akibat sepsis jauh lebih besar dibandingkan akibat sindrom koroner akut ataupun stroke.

Mortalitas bisa mencapai $30 \%$ pada sepsis hingga $80 \%$ pada syok sepsis. Dari studi tersebut diketahui insiden sepsis berkisar antara 22 hingga 240 per 100.000 , sepsis berat 13 hingga 300 per 100.000, dan syok sepsis 11 per 100.000. Dari suatu studi observasional terhadap pasien sepsis 
berat dan syok sepsis di RSUPN dr. Cipto Mangunkusumo, Jakarta pada tahun 2012-2013, diketahui bahwa angka kematian pada sepsis berat dan syok sepsis berkisar $61 \%$. Tingginya mortalitas pada sepsis tidak lepas dari masalah keterlambatan diagnosis dan tata laksana (Pangalila F, et.al). Pada tahun 2001 dilaporkan bahwa insidensi sepsis di Amerika terjadi pada 3 dari 1000 populasi, 51,1\% dirawat di ICU dan 17,3\% mendapat bantuan ventilasi mekanik (Angus, et.al. 2001). Pada tahun 2004 dilaporkan di Inggris bahwa 27\% pasien yang masuk RS menderita sepsis berat dalam 24 jam pertama, walaupun angka kematiannya menurun dari 48,3\% (tahun 1996) menjadi 44,7\% (tahun 2004) tetapi total kematian pada populasi meningkat dari 9000 menjadi 14.000. Dalam 10-15 tahun terakhir terjadi penurunan angka kematian yang disebabkan oleh sepsis, walaupun masih tetap tinggi (30-50\%) (Harrison, et.al. 2006). Early Goal Directed Therapy (EGDT) yang dikembangkan oleh Rivers pada tahun 2001 dapat menurunkan angka kematian dari 46,5\% menjadi 30,5\%. CDC National Center of Hospital Statistics tahun 2011 melaporkan bahwa beban ekonomi sangat tinggi pada pasien sepsis berat dan syok sepsis, diperkirakan 14,6 juta dolar telah dihabiskan untuk perawatan septikemia, dan sejak tahun 1997 sampai 2008 terjadi peningkatan biaya perawatan pasien di rumah sakit sekitar rata-rata 11,9\%. Mitra pengabdian masyarakat Fakultas Kedokteran Universitas Sumatera Utara (FK USU) pada kegiatan ini adalah ibu-ibu PKK, kader Posyandu di Kelurahan Kesawan, Kecamatan Medan Barat yang terletak sekitar 6 km dari FK USU dan dihuni oleh sekitar 98.203 jiwa. Berdasarkan visi misi FK USU saat ini yang menitik beratkan pada penanggulangan penyakit infeksi sedangkan program kerja Puskesmas Kecamatan Medan Barat juga menitikberatkan pada peningkatan kualitas masyarakat. Dikarenakan sepsis masih menjadi masalah besar baik di negara maju maupun berkembang, suatu program promotif dan preventif dalam penanggulangan sepsis di Kecamatan Medan Barat sangat diperlukan untuk menurunkan angka sepsis di Indonesia dan sekaligus meningkat kualitas kesahatan masyarakat.

\section{METODE PELAKSANAAN}

Metode yang dilakukan pada kegiatan ini adalah dengan cara menilai data dan tingkat pengetahuan dasar para ibu-ibu PKK dan kader Posyandu mengenai sepsis dan infeksi berat menggunakan kuesioner Sepsis Knowledge Scale yang telah diterjemahkan dan divalidasi ke dalam Bahasa Indonesia. Kemudian dilakukan edukasi melalui penyuluhan dan pelatihan mengenai upaya promotif dan preventif infeksi berat dan sepsis pada peserta. Hasil dari kegiatan kemudian dinilai dengan mengisi kembali kuesioner pengetahuan sepsis dan kuesioner perilaku. Akhirnya, kegiatan ditutup dengan penyerahan buku panduan, poster dan fasilitasi PKK dan Posyandu dalam deteksi dini, penanganan awal dan pencegahan sepsis.

Pelaksanaan kegiatan ini berlangsung di ruangan PKK Kecamatan Medan Barat pada hari Sabtu, 29 Juni 2019.

\section{HASIL DAN PEMBAHASAN}

Sebelum dilaksanakan kegiatan penyuluhan dilakukan survei tingkat pengetahuan peserta mengenai penanganan infeksi berat dilaksanakan untuk mengukur keberhasilan program ini. Sejumlah 29 orang peserta berusia dewasa yang terdiri dari 20 orang perempuan (72.4\%) dan 9 orang laki-laki (27.6\%) diberikan penyuluhan mengenai pengenalan dan penangan infeksi berat. Berdasarkan variabel karakteristik, sebanyak 21 orang perestanya adalah perempuan $(72.4 \%)$ dengan rerata usia 46 tahun (rentang usia $16-73$ tahun). Pekerjaan sebagian besar peserta adalah ibu rumah tangga sebanyak 13 orang (44.8\%), wiraswasta 12 orang (41.4\%), karyawan 3 orang $(10.3 \%)$ dan guru sebanyak 1 orang $(3.4 \%)$. Berdasarkan tingkat pendidikan terakhir, didapatkan sebagian besar peserta memiliki pendidikan terakhir lulusan SMU sebanyak 16 orang $(55.2 \%)$, lulusan SMP sebanyak 7 orang (24.1), lulusan perguruan tinggi sebanyak 3 orang (10.3\%), dan lulusan SD sebanyak 3 orang $(10.3 \%)$. 
Jika ditinjau dari segi pengetahuan dan informasi mengenai infeksi berat, sebanyak 18 orang (62\%) pernah mendengar ataupun mengetahui informasi mengenai infeksi berat, sementara 11 orang $(38 \%)$ tidak pernah mengetahui informasi mengenai infeksi berat.

Pada uji bivariat, berdasarkan hasil pre-test didaptkan hasil bahwa pengetahuan peserta terbanyak sebelum diberikan penyuluhan adalah kategori cukup sebanyak 15 orang (52\%), dan pada kategori baik sebanyak 14 orang (48\%). Hal ini menunjukkan bahwa tingkat pengetahuan peserta mengenai infeksi berat masih dalam kategori cukup.

Sementara itu, setelah dilakukan post-test didapatkan hasil yang sama pula yakni tingkat pengetahuan peserta terbanyak setelah diberikan penyuluhan adalah kategori cukup sebanyak 15 orang (52\%), dan pada kategori baik sebanyak 14 orang (48\%). Selanjutnya dari hasil analisis didapatkan skor $\mathrm{Z}$ sebesar 0,001 dengan nilai $\mathrm{p}$ value sebesar $1,000(\mathrm{p}>\alpha$ (, sehingga diputuskan tidak ada perbedaan pada tingkat pengetahuan peserta mengenai infeksi berat sebelum dan sesudah diberikan penyuluhan (Tabel 4.1).

\begin{tabular}{cccccccc}
\hline \multirow{2}{*}{$\begin{array}{c}\text { Tingkat } \\
\text { Pengetahuan }\end{array}$} & \multicolumn{2}{c}{$\begin{array}{c}\text { Pre }- \\
\text { test }\end{array}$} & $\begin{array}{c}\text { Post } \\
\text { test }\end{array}$ & Skor & Nilai \\
\cline { 2 - 5 } & $\mathrm{N}$ & $\%$ & $\mathrm{~N}$ & $\%$ & $\mathrm{Z}$ & $\mathrm{p}$ \\
\hline Baik & 14 & 48 & 14 & 48 & 0,001 & 1,000 \\
Cukup & 15 & 52 & 15 & 52 & & \\
Kurang & 0 & 0 & 0 & 0 & & \\
Total & 29 & 100 & 29 & 100 & & \\
\hline
\end{tabular}

Tabel 3.1. Perbedaan tingkat pengetahuan peserta sebelum dan sesudah pemberian penyuluhan

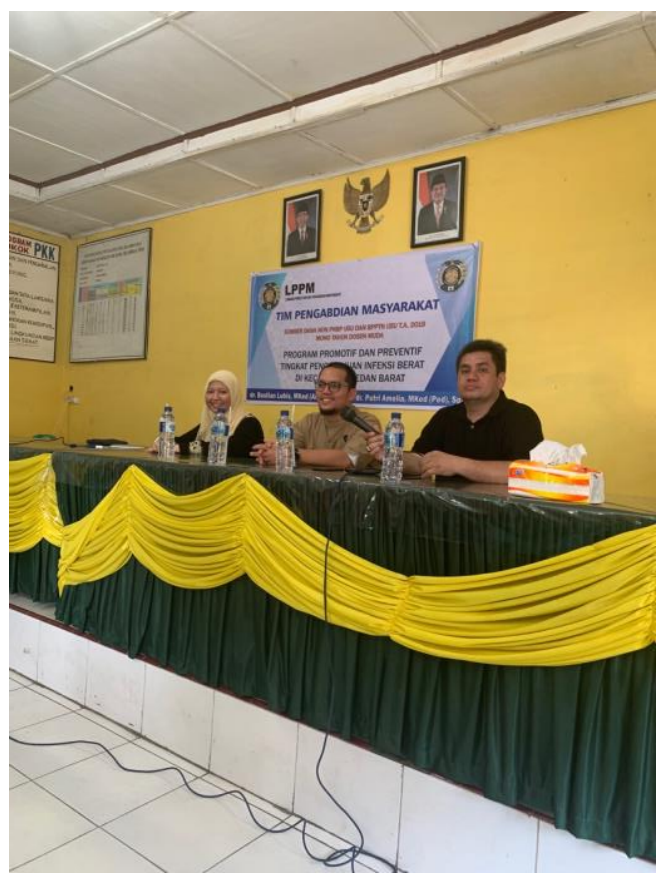

Gambar 3.1 Pembicara Penyuluhan Infeksi Berat 


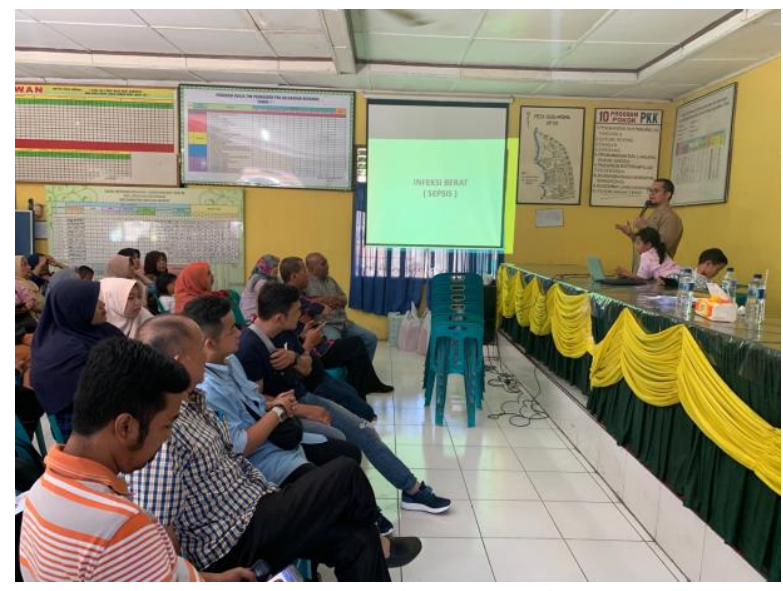

Gambar 3.2 Penyampaian Materi Penyuluhan

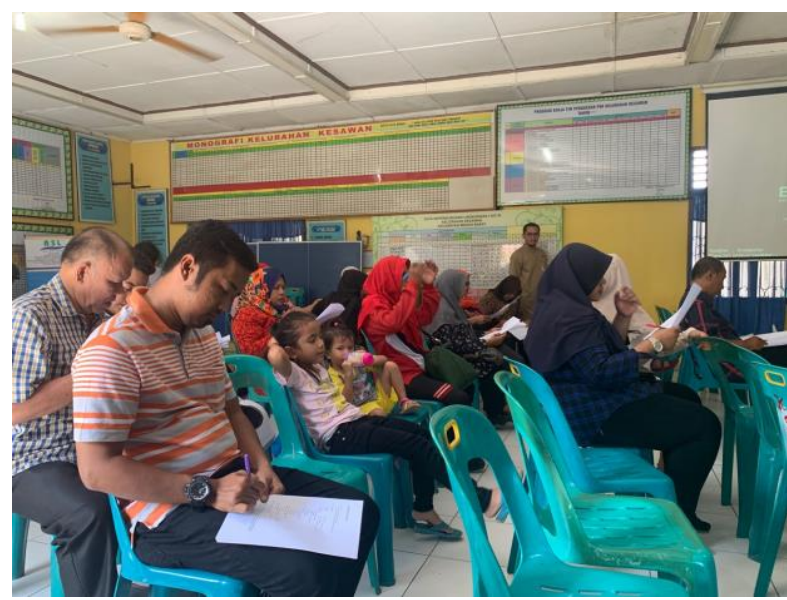

Gambar 3.3 Pelaksanaan Pre-test

\section{KESIMPULAN}

\subsection{Kesimpulan}

Karakteristik dari 29 orang peserta kegiatan pengabdian masyarakat disusun berdasarkan tingkat pendidikan terakhir dan jenis kelamin. Sebagian besar pesrta dengan pendidikan terakhir lulusan SMU sebanyak 16 orang $(55.2 \%)$. Kegiatan dihadiri oleh 20 orang perempuan $(72,4 \%)$ dan 9 orang laki-laki $(27,6 \%)$. Tidak ada perbedaan tingkat pengetahuan peserta sebelum dan sesudah penyuluhan mengenai infeksi berat, yakni berada pada kategori cukup sejumlah 15 orang (52\%) dan kategori baik sejumlah 14 orang (48\%).

\subsection{Saran}

Tim penggerak PKK Kelurahan Kesawan sebaiknya terus mengembangkan ilmu yang telah didapat dan melaksanakan penyuluhan bagi anggota tim penggerak PKK kelurahan lain di Kecamatan Medan Barat.

\section{UCAPAN TERIMAKASIH}

Ucapan terima kasih kami sampaikan kepada Universitas Sumatera Utara, Wakil Rektor III yang membawahi kegiatan pengabdian masyarakat ini, Dekan Fakultas Kedokteran Universitas Universitas Utara, Dinas Kesehatan Kota Medan, dan mitra kami yaitu PKK Kecamatan Medan Barat, Kota Medan yang telah membantu kami dalam keberhasilan penyelenggaraan pengabdian masyarakat ini. 


\section{DAFTAR PUSTAKA}

Bone, R.C., Balk, R.A., Cerra, F.B., Dellinger, R.P., Fein, A.M., Knaus, W.A., et al. 1992. Definitions for sepsis and organ failure for the use of innovative therapies in sepsis. Chest. 101: 1644-55.

Patrick, J.N. 2006. Infectious Disease and Bioterrorism. In: Anaesthesia and Uncommon Disease. Philadhelpia; Saunder Elsevier, 5th ed; 377-410.

Knoop, S.T., Skrede, S., Langeland, N., Flaatten, H.K. 2017. Epidemiology and impact on allcause mortality of sepsis in Norwegian hospitals: Anational retrospective study. PLOS ONE |https://doi.org/10.1371/journal.pone.0187990 [November 17, 2013].

Perhimpunan Dokter Intensive Care Indonesia (PERDICI). Penatalaksanaan sepsis dan syok septik Optimalisasi fasthugsbid. Pangalila F, Mansjoer A. ISBN :978-602-17737-4-1

Angus, D.C., linde-Zwirble, W.T., Lidicker J., et al. 2001. Epidemiology of severe sepsis in the United States: Analysis of incidence, outcome, and associated costs of care. Crit Care Med. 29: 1303-10.

Harrison, D.A., Welch, C.A., Eddleston, J.M. 2006. The epidemiology of severe sepsis in England,Wales, and Northern Ireland, 1996 to 2004: secondary analysis of a high quality clinicaldatabase, the ICNARC Case Mix Programme Database. Crit care. 10(2): R42.

Rivers, E., Nguyen, B., et al. 2001. Early goal directed therapy in the treatment of severe sepsis andseptic shock. N Engl J Med. 345: 1368-77. 